\title{
HUBUNGAN KECERDASAN EMOSIONAL DENGAN MINAT BELAJAR SISWA KELAS IV SDN 173418 POLLUNG
}

\author{
Novia Banjarnahor, Regina Sipayung, Darinda Sofia Tanjung \\ Surel: noviabanjarnahormarbun@gmail.com
}

\begin{abstract}
This study aims to determine the relationship between emotional intelligence and learning interest in fourth grade students of SDN 173418 Pollung. The sample in the study consisted of 34 students. This type of research is quantitative. The data collection tool used to determine student learning motivation was a questionnaire that had been tested for validation and reliability. Both classes are normally distributed because $L_{\text {hitung }} \leq_{\text {Ltabel }}$. From the Linearity test, it is known that the significant value of deviation from linearity is $1.80 \leq 3.32$, it can be concluded that there is a linear relationship between emotional intelligence and student learning interest. The t test was conducted at the real level $(\alpha=0.05)$ that tcount $\geq$ $t_{-}$(table), namely $5.925 \geq 2.306$, this proves that $H_{a}$ is accepted, so the author concludes that there is a significant relationship between emotional intelligence and the learning interest of fourth grade students of SDN 173418 Pollung.
\end{abstract}

Keywords: Relationship, Emotional Intelligence, Learning Interest.

\begin{abstract}
ABSTRAK
Penelitian ini bertujuan untuk mengetahui hubungan antara kecerdasan emosional dengan minat belajar siswa kelas IV SDN 173418 Pollung. Sampel dalam penelitian terdiri dari 34 siswa. Jenis penelitian ini adalah kuantitatif. Alat pengumpul data yang digunakan untuk mengetahui motivasi belajar siswa adalah angket yang telah diuji validasi dan reliabilitasnya. Kedua kelas tersebut berdistribusi normal karena Lhitung $\leq$ Ltabel. Dari uji Linieritas diketahui nilai signifikan penyimpangan dari linieritas sebesar $1,80 \leq 3,32$ maka dapat disimpulkan bahwa terdapat hubungan linier antara kecerdasan emosional dengan minat belajar siswa. Uji t dilakukan pada taraf nyata $(\alpha=0,05)$ bahwa thitung $\geq \mathrm{t} \quad$ (tabel) yaitu $5,925 \geq 2,306$, ini membuktikan bahwa Ha diterima, sehingga penulis menyimpulkan ada hubungan yang signifikan antara kecerdasan emosional dengan pembelajaran. minat siswa kelas IV SDN 173418 Pollung.
\end{abstract}

Kata Kunci: Hubungan, Kecerdasan Emosional, Minat Belajar.

\section{PENDAHULUAN}

Pendidikan adalah proses pengembangan potensi, kemampuan dan kapasitas manusia yang mudah dipengaruhi oleh kebiasaan. Kebiasaan yang baik, didukung dengan alat (media) yang disusun sedemikian rupa sehingga pendidikan dapat digunakan untuk menolong orang lain atau diri nya sendiri. Dalam mencapai tujuan yang telah ditetapkan. Pendidikan merupakan kegiatan yang sangat esensial dalam kehidupan manusia untuk membentuk insan yang dapat memecahkan permasalahan dalam kehidupannya. 
Potensi diri yang akan dibahas paling mendalam adalah kecerdasan.

Kecerdasan berarti pintar dan cerdik, serta cepat tanggap dalam menghadapi masalah dan cepat mengerti jika mendengar informasi baru yang diterimanya. Kecerdasan adalah kesempurnaan perkembangan akal budi untuk memecahkan masalah yang dihadapi yang menuntut kemampuan seseorang untuk berpikir. Namun, kecerdasan yang paling memprediksi tingkat kesuksesan seseorang adalah kecerdasan emosional.

Kecerdasan emosional adalah kemampuan seseorang dalam mengenali emosi diri sendiri, mengelola emosi diri sendiri, memotivasi diri sendiri, mengenali emosi orang lain dan kemampuan membina hubungan dengan orang lain. Kemampuan setiap individu untuk bereaksi secara emosional terjadi semenjak dalam kandungan hingga akhir masa hidupnya. Dalam melaksakan kegiatan atau aktivitas dalam kehidupannya, manusia bekerja dengan seperangkat alat-alat kejiwaan dalam diri nya, baik yang bersifat fisik (jasmani) maupun yang bersifat psikis (rohani) dalam proses pembelajaran.

Pada proses pembelajaran emosional ini sangat berpengaruh. Keberhasilan di sekolah bukan diramalkan oleh kumpulan fakta seorang siswa dalam kemampuannya membaca, melainkan oleh ukuranukuran emosional dan sosial. Siswa yang menggunakan emosionalnya dengan baik dalam pembelajaran akan lebih memahami emosinya sendiri dan emosi orang lain. Siswa yang tidak mampu mengelola emosinya dengan baik akan menimbulkan siswa yang mudah tersinggung ketika berbicara dengan teman sekelasnya sehingga memicu timbulnya perkelahian.

Pengelolaan kecerdasan emosional yang baik dapat menentukan keberhasilan siswa dalam membangun minat belajar yang tinggi dan dapat mengurangi perilaku agresif. Ketika siswa memiliki kecerdasan emosi yang baik ditandai dengan kemampuan mengenali emosi diri sendiri maupun orang lain, membina hubungan kerjasama yang baik, maka minat belajar juga semakin tinggi, dengan bertukar pikiran, saling berpendapat, memberikan banyak saran terhadap sesama teman menghasilkan banyak jawaban yang bervariasi didalam menyelesaikan masalah yang mereka hadapi. Siswa lebih terlatih bahwa jalan menyelesaikan masalah harus dengan mengelola emosi dengan bantuan minat yang dimilikinya.

Minat belajar pada umumnya merupakan bagian terpenting yang harus dimiliki siswa dalam proses pembelajaran. Karena, minat belajar dapat mempengaruhi proses dan kualitas hasil belajar siswa. Dengan demikian, minat belajar dapat ditimbulkan dengan membandingkan adanya suatu kebutuhan pada siswa sehingga dia rela belajar tanpa paksaan.

Minat terhadap sesuatu merupakan hasil belajar yang akan menyokong belajar selanjutnya dan minat akan membantu seseorang 
Novia Banjarnahor, Regina Sipayung, Darinda Sofia Tanjung : Hubungan ...

mempelajarinya. Minat besar pengaruhnya terhadap belajar, karena apabila dia belajar dengan paksaan tanpa adanya minat dia akan malas dan menimbulkan rasa ngantuk saat belajar. Minat sebagai aspek kewajiban bukan aspek bawaan, melainkan kondisi yang terbentuk setelah dipengaruhi oleh lingkungan. Karena itu minat sifatnya berubahubah dan sangat tergantung pada emosi yang dimiliki oleh setiap individu.

Minat belajar adalah suatu kemampuan umum yang dimiliki siswa untuk mencapai hasil belajar yang optimal yang dapat ditunjukkan dengan kegiatan belajar. Setiap orang memiliki minat belajar yang berbeda, maka guru perlu mengembangkan dengan menggunakan pembelajaran yang menumbuhkan minat belajar siswa.

\section{METODE PENELITIAN}

Dalam penelitian ini terdapat dua variabel yaitu variabel bebas dan variabel terikat. Variabel bebas pada penelitian ini adalah kecerdasan emosional (variabel $\mathrm{X}$ ) sedangkan Variabel terikat dalam penelitian ini adalah minat belajar siswa (variabel Y).

Jika melakukan suatu penelitian harus memerlukan populasi. Populasi adalah wilayah generalisasi yang terdiri atas obyek/subyek yang mempunyai kualitas dan karakteristik tertentu yang ditetapkan oleh peneliti untuk dipelajari dan kemudian ditarik kesimpulannya (dalam buku Sugiyono 2018: 80).
Sampel adalah sebagian dari jumlah dan karakteristik yang dimiliki oleh populasi tersebut. Dalam penelitian ini sampel yang digunakan adalah Sampling total. Sugiyono (2015: 118) Sampling total adalah sampling yang menjadikan seluruh anggota populasi sebagai sampel penelitian. Hal ini disebabkan karena populasi penelitian berjumlah 34 orang dan jumlahnya kurang dari 100 orang.

Data primer adalah data yang diperoleh peneliti secara langsung (dari tangan pertama) melalui angket kuesioner dan data sekunder merupakan sumber data yang tidak langsung diberikan kepada pengumpul data. Dalam penelitian ini jenis data yang digunakan oleh peneliti adalah jenis data primer yang langsung diperoleh dari subjek peneliti.

Pengumpulan data dilakukan dengan memberi kuesioner kepada siswa. Sebelum responden mengisi kuesioner, peneliti meminta responden untuk melihat arahan untuk mengisi kuesioner. Setelah itu, responden dipersilahkan mengisi kuesioner yang telah disediakan, yaitu kuesioner Kecerdasan Emosional dan Minat Belajar Siswa dan kuesioner tersebut dikumpulkan pada hari itu juga.

Angket atau kuesioner merupakan teknik pengumpulan data yang dilakukan dengan cara memberi seperangkat pertanyaan atau pernyataan tertulis. 

Tabel 1. Kisi-kisi Instrumen Penelitian

\begin{tabular}{lll}
\hline Variabel & Indikator & Butir Soal \\
\hline Kecerdasan & 1. Kesadaran diri & $1,2,3,4$ \\
Emosional & 2. Mengelola emosi & $5,6,7,8$ \\
& 3. Motivasi & $9,10,11,12$ \\
& 4. Empati & $13,14,15,16$ \\
\multirow{2}{*}{ Minat Belajar } & 5. Membina hubungan & $17,18,19,20$ \\
Siswa & 1. Tekun menghadapi tugas & $1,2,3,4,5$ \\
& 2. Menunjukkan minat & $6,7,8,9,10$ \\
& 3. Lebih senang bekerja mandiri & $11,12,13,14,15$ \\
& 4. Minat berbobot emosional & $16,17,18,19,20$ \\
\hline
\end{tabular}

Skala Likert digunakan untuk mengukur sikap, pendapat, dan persepsi seseorang atau sekelompok orang tentang fenomena sosial.

Tabel 2. Skor Alternatif Jawaban

\begin{tabular}{cc}
\hline Alternatif Jawaban & $\begin{array}{c}\text { Skor Untuk } \\
\text { Pertanyaan }\end{array}$ \\
\hline Sangat Setuju & 5 \\
Setuju & 4 \\
Ragu-ragu & 3 \\
Tidak Setuju & 2 \\
Sangat Tidak Setuju & 1 \\
\hline
\end{tabular}

Dokumentasi adalah suatu teknik pengumpulan data dengan menghimpun dan menganalisis dokumen tertulis maupun tidak tertulis.

Instrumen yang baik apabila memenuhi syarat sebagai instrumen yang standar. Instrumen yang standar apabila instrumen itu valid atau tepat. Adapun rumusnya sebagai berikut: $r_{x y}=\frac{N \Sigma X Y-(\Sigma X)(\Sigma Y)}{\sqrt{\left\{N \Sigma X^{2}-(\Sigma X)^{2}\right\}\left\{N \Sigma Y^{2}-(\Sigma Y)^{2}\right\}}}$ (Arikunto, 2017: 87)

Keterangan:

$\mathrm{r}_{\mathrm{xy}}=$ koefisien korelasi antara variabel $\mathrm{x}$ dan $\mathrm{y}$

$\Sigma x y=$ jumlah perkalian $\mathrm{x}$ dengan $\mathrm{y}$

$\mathrm{X}=$ skor tiap item
Dengan kisaran 1-5 dengan alternatif jawaban, yaitu: "1 = Sangat tidak setuju", " $2=$ Tidak setuju" " $3=$ Raguragu" " $4=$ Setuju" "5 = Sangat setuju". $\mathrm{Y}=$ skor total

$\mathrm{N}$ = sampel

\section{Rumus} reliabilitas menggunakan rumus Alpha menurut Arikunto (2017: 122 ) adalah sebagai berikut:

$$
r_{11}=\left(\frac{n}{(n-1)}\right)\left(1-\frac{\sum \sigma_{b}^{2}}{\sigma_{t}^{2}}\right)
$$

Keterangan:

$r_{11}=$ Reliabilitas angket yang dicari

$\sum \sigma_{b}^{2}=$ Jumlah varians skor tiap-tiap item

$\sigma_{t}^{2}=$ Varians total

$\mathrm{n} \quad=$ Banyaknya butir pertanyaan

Analisis statistik dibagi menjadi dua yaitu statistik deskriftif dan statistik inferenssial. Sedangkan analisis non statistik berangkat dari data kualitatif. Pada analisis nonstatistik masalah dilihat dari berbagai segi dan data yang kumpulkan bukan secara random atau mekanik tetapi dikuasai oleh peneliti. 
Novia Banjarnahor, Regina Sipayung, Darinda Sofia Tanjung : Hubungan ...

Variabel bebas $(\mathrm{X})$ dan berbantuan program SPSS versi 22.0.

Menurut Noor (2017: 174-175)

Rumus yang dipakai adalah rumus Liliefors, yaitu:

$Z i=\frac{\mathrm{Xi}-\mathrm{X}}{\mathrm{s}}$

Keterangan:

$\mathrm{X}=$ Rata-rata

$\mathrm{S}=$ Simpangan baku

Untuk mencari $F_{\text {hitung }}$ dilakukan dengan bantuan program SPSS versi 22.0. Rumus uji linearitas data adalah sebagai berikut:

$Y=a+b X$

Keterangan :

$\mathrm{Y}=$ Variabel Terikat

$\mathrm{X}=$ Variabel Bebas

$\mathrm{a}=$ Nilai Konstanta

$\mathrm{b}=$ Nilai Koefisien Regresi

Untuk mengetahui ada tidaknya pengaruh antara variabel bebas (X) dengan variabel terikat (Y), dengan rumus korelasi Product Moment yaitu:

$r_{x y}=\frac{N \sum X Y-\left(\sum X\right)\left(\sum Y\right)}{\sqrt{\left\{N \sum X^{2}-\left(\sum X\right)^{2}\right\}\left\{N \sum Y^{2}-\left(\sum Y\right)^{2}\right\}}}$ ...(Sugiyono, 2018: 183)

Keterangan: $\mathrm{r}_{\mathrm{xy}}=$ Koefisien korelasi product moment

$\mathrm{N}=$ Jumlah seluruh siswa

$\sum \mathrm{X}=$ Skor item

$\sum \mathrm{Y}=$ Skor total seluruh siswa $\sum X Y=$ Jumlah hasil perkalian antara skor " $X$ " dan skor "Y"

Untuk mengetahui apakah variabel $\mathrm{X}$ memiliki pengaruh yang signifikan terhadap variabel $Y$ dilakukan pengujian terhadap hipotesis dengan menggunakan uji $\mathrm{t}$ sebagai berikut:

$t=\frac{r \sqrt{n-2}}{\sqrt{1-r^{2}}} \ldots \ldots \ldots \ldots \ldots \ldots$

(Sugiyono, 2017: 187)

Keterangan:

$r=$ koefisien korelasi

$n=$ sampel

Jika $\mathrm{t}$ hitung $\geq \mathrm{t}$ tabel : hipotesis alternatif diterima

Jika $\mathrm{t}$ hitung $\leq \mathrm{t}$ tabel : hipotesis alternatif ditolak

\section{HASIL PENELITIAN DAN PEMBAHASAN}

Setelah dilakukan perhitungan dengan menggunakan SPSS Versi 22.0 pengujian normalitas yaitu dengan menggunakan uji Shapiro-Wilk, diketahui nilai signifikansi $0,05 \%$.

Tabel 3. Uji Normalitas Instrumen

Tests of Normality

\begin{tabular}{lccccccc}
\hline & \multicolumn{3}{c}{ Kolmogorov-Smirnova } & \multicolumn{3}{c}{ Shapiro-Wilk } \\
& Statistic & $\mathrm{df}$ & \multicolumn{1}{c}{ Sig. } & Statistic & $\mathrm{df}$ & \multicolumn{1}{c}{ Sig. } \\
kecerdasan_emosional & .084 & 34 & $.200^{*}$ & .982 & 34 & .847 \\
minat_belajar & .121 & 34 & $.200^{*}$ & .967 & 34 & .373 \\
\hline
\end{tabular}

*. This is a lower bound of the true significance.

a. Lilliefors Significance Correction

Hasil perhitungan uji linieritas pada variabel bebas dengan variabel terikat pada penelitian ini adalah sebagai berikut: 
SCHOOL EDUCATION JOURNAL VOLUME 10 NO. 4 DESEMBER 2020

Tabel 4. Uji Linearitas

\begin{tabular}{|c|c|c|c|c|c|c|c|}
\hline \multicolumn{8}{|c|}{ ANOVA Table } \\
\hline \multirow{4}{*}{$\begin{array}{l}\text { minat belajar } \\
* \text { kecerdasan } \\
\text { emosional }\end{array}$} & & & Sum of Squares & Df & Mean Square & $\mathrm{F}$ & Sig. \\
\hline & Between & (Combined) & 3396.696 & 21 & 161.747 & 4.230 & .007 \\
\hline & Groups & Linearity & 2016.919 & 1 & 2016.919 & 52.749 & .000 \\
\hline & & $\begin{array}{l}\text { Deviation from } \\
\text { Linearity }\end{array}$ & 1379.777 & 20 & 68.989 & 1.804 & .147 \\
\hline & \multicolumn{2}{|c|}{ Within Groups } & 458.833 & 12 & 38.236 & & \\
\hline & \multicolumn{2}{|l|}{ Total } & 3855.529 & 33 & & & \\
\hline
\end{tabular}

\section{Uji Korelasi}

untuk membuktikan adanya pengaruh

Analisis korelasi dengan yang signifikan antara variabel $\mathrm{x}$ menggunakan rumus $r_{x y}$ bertujuan dengan variabel $y$.

\section{Tabel 5. Hasil Uji Korelasi}

\begin{tabular}{llrr}
\multicolumn{3}{c}{ Correlations } & \\
\hline \multirow{2}{*}{ kecerdasan } & kecerdasan emosional & minat belajar \\
emosional & Pearson Correlation & 1 & $.723^{* * *}$ \\
& Sig. (2-tailed) & & .000 \\
minat belajar & $\mathrm{N}$ & 34 & 34 \\
& Pearson Correlation & $.723^{* *}$ & 1 \\
& Sig. (2-tailed) & .000 & 34 \\
\hline
\end{tabular}

**. Correlation is significant at the 0.01 level (2-tailed).

Pengujian hipotesis pada cara membandingkan thitung dengan penelitian ini dilakukan dengan $t_{\text {tabel. }}$ Kriteria pengujian dengan menggunakan uji t dengan berbantuan menggunakan uji t adalah jika $t_{\text {hitung }} \geq$ program SPSS Versi 22.0. Uji $\mathrm{t} \quad \mathrm{t}_{\text {tabel }}$ hipotesis alternatif diterima dan digunakan untuk mengetahui ada jika $t_{\text {hitung }} \leq t_{\text {tabel }}$ hipotesis alternatif tidaknya pengaruh variabel bebas ditolak. terhadap variabel terikat yaitu variabel pola asuh orangtua terhadap motivasi belajar. Pengujian hipotesis dengan menggunakan uji $\mathrm{t}$ dilakukan dengan

Berikut akan disajikan tabel dari hasil pengujian hipotesis dengan berbantuan program SPSS ver 22.0

Tabel 6. Hasil Uji Hipotesis

Coefficients

\begin{tabular}{|c|c|c|c|c|c|}
\hline \multirow[b]{2}{*}{ Model } & \multicolumn{5}{|c|}{ Unstandardized } \\
\hline & $\mathrm{B}$ & Std. Error & Beta & $\mathrm{t}$ & Sig. \\
\hline 1 (Constant) & 7.914 & 12.256 & & .646 & .523 \\
\hline kecerdasan emosional & .872 & .147 & .723 & 5.925 & .000 \\
\hline
\end{tabular}

\section{Pembahasan}

1. Berdasarkan uji normalitas antara kecerdasan emosional dengan minat belajar siswa diperoleh nilai signifikansi kecerdasan emosional adalah $0,847 \leq 0,933$ 
Novia Banjarnahor, Regina Sipayung, Darinda Sofia Tanjung : Hubungan ...

sedangkan minat belajar siswa signifikannya $0,373 \leq 0,933$. Berdasarkan hasil perhitungan tersebut dapat diketahui bahwa nilai signifikansi dari kecerdasan emosional dan minat belajar siswa berdistribusi normal.

2. Berdasarkan uji linieritas antara variabel bebas kecerdasan emosional dengan variabel terikat minat belajar siswa dapat dilihat dari nilai sig. Deviation from Linearity, $\mathrm{F}_{\text {hitung }}$ sebesar 1,80. Nilai sig. Deviation from Linearity lebih kecil dari $\mathrm{F}$ tabel sebesar 3,32 maka dapat disimpulkan bahwa hubungan antara kecerdasan emosional dengan minat belajar siswa bersifat linier.

3. Berdasarkan uji korelasi dari hasil penelitian ini menunjukkan bahwa kecerdasan emosional memiliki hubungan dengan minat belajar siswa hal tersebut terbukti dari nilai $r_{x y} 0,72$. Berdasarkan tabel interpretasi nilai $r$, korelasi $\mathrm{r}_{\mathrm{xy}} 0,72$ terletak pada rentang nilai r 0,600-0,800 maka, dapat disimpulkan tingkat hubungan antara variabel kecerdasan emosional dan minat belajar siswa memiliki hubungan yang tinggi atau kuat.

4. Berdasarkan uji Hipotesis berdasarkan hasil peneliti diketahui bahwa nilai thitung sebesar 5,925 dan tabel sebesar 2,306, sehingga $t_{\text {hitung }} \geq t_{\text {tabel }}$ maka $\mathrm{H}_{\mathrm{a}}$ diterima yaitu terdapat hubungan yang positif dan signifikan antara kecerdasan emosional dengan minat belajar siswa.

\section{SIMPULAN}

Berdasarkan hasil analisis data dan pengujian hipotesis serta pembahasan, maka dapat ditarik kesimpulan sebagai berikut: Kecerdasan emosional dengan minat belajar siswa memiliki pengaruh yang positif dan signifikan, hal tersebut terbukti dari nilai t sebesar 5,925 $\geq$ 2,306 di SDN 173418 Pollung.

Dari hasil penelitian di SDN 173418 Pollung menunjukkan bahwa kecerdasan emosional sangat dipengaruhi oleh minat belajar siswa. Hasil penelitian ini menunjukkan bahwa kecerdasan emosional memiliki hubungan dengan minat belajar siswa hal tersebut terbukti dari $\mathrm{r}_{\mathrm{xy}} \quad 0,72$. Berdasarkan tabel interprestasi nilai $r$, korelasi $r_{x y} 0,72$ terletak pada rentang nilai $r$ 0,6000,800, maka dapat disimpulkan tingkat hubungan antara variabel kecerdasan emosional dengan minat belajar siswa memiliki pengaruh hubungan yang tinggi dengan nilai $t_{\text {hitung }} 5,925 \geq \mathrm{t}_{\text {tabel }}$ 2,306 maka dapat disimpulkan bahwa kecerdasan emosional memiliki hubungan yang signifikan dengan minat belajar siswa.

\section{DAFTAR RUJUKAN}

Alex, Sobur. 2016. Psikologi Umum. Bandung: Pustaka Setia.

Arikunto Suharsimi. 2017. Prosedur Penelitian. Jakarta: Rineka Cipta. 
Goleman, Daniel. 2018. Emotional Interligence. Jakarta: Gramedia Pustaka Utama.

Istirani \& Pulungan Intan. 2018. Ensiklopedia Pendidikan. Medan: Media Persada.

Khairani Makmun. 2017. Psikologi Belajar. Yogyakarta: Aswaja Pressindo.

Lusi Marleni. 2016. Faktor-faktor yang Mempengaruhi Minat Belajar Siswa Kelas VIII SMP Negeri 1 Bengkinang. Journal Cendekia. Volume 1, Nomor 1, 149-159.

Margono. 2014. Metode Penelitian Pendidikan. Jakarta: Rineka Cipta

Much Solehudin. 2018. Peran Guru PAI dalam Mengembangkan Kecerdasan Emosional (EQ) dan Kecerdasan Spiritual (SQ) Siswa SMK Komputama Majenang. Jurnal Tawadhu. Volume 1, Nomor 3, 303-325.

Muhammad Ali dan Muhammad Asrori. 2020. Psikologi remaja. Jakarta: PT.bumi Aksara.

Muhammedi. 2017. Psikologi Belajar. Larispa.

Nisrina, Nida, Ajeng, dkk. 2018. Hubungan Antara Kecerdasan Emosional dengan Prestasi Belajar Matematika Siswa Kelas IV SD Negeri Kutabumi IV Kabupaten Tangerang. Jurnal Taman Cendekia, Volume 2, Nomor 3, 198205.

Noor, Juliansyah. 2017. Metodologi Penelitian: Skripsi, Tesis, Disertasi \& Karya Ilmiah. Jakarta: Prenada Media Group.
Rizky Meutia Karina, Alfiati Syafrina, Sy. Habibah. Hubungan antara Minat Belajar dengan Hasil Belajar Siswa dalam Mata Pelajaran IPA pada kelas $V$ SD Negeri Garot Geuceu Aceh Besar. Jurnal Ilmiah Pendidikan Guru sekolah Dasar. Volume 2, Nomor 1, 61-77.

Sardiman. 2014. Interaksi \& Motivasi Belajar Mengajar. Rajawali Pers.

Sinaga, Reflina. 2017. Hubungan Kecerdasan Emosional dengan Prestasi Belajar pada Siswa Kelas V SD Negeri 178491 Kecamatan Pintu Pohan Meranti Kabupaten Toba samosir.

Sugiyono. 2015. Metode penelitian pendidikan. Bandung: Alfabeta.

Supriyono dan Ahmadi. 2008. Psikologi Belajar. Jakarta: Rineka Cipta.

Ulya Illahi, dkk. 2018. Hubungan antara Kecerdasan Emosional dengan Perilaku agresif Remaja dan Implikasinya dalam Bimbingan dan Konseling. Jurnal Riset Tindakan Indonesia. Volume 3, Nomor 2, 68-74.

Zaki Al Fuad dan Zuraini. Faktorfaktor yang Mempengaruhi Minat belajar Siswa kelas I SDN 7 Kute Panang. Jurnal Tunas Bangsa. 42-54. 